\title{
Baker's Cyst on F-18 FDG PET/CT in a Patient with Ocular Melanoma
}

\author{
Oküler Melanom Hastasinda F-I 8 FDG PET/BT'de Baker Kisti
}

Hakan Cayvarl, Erkan Derebek

Dokuz Eylül University Medical Faculty, Department of Nuclear Medicine, Izmir, Turkey

\begin{abstract}
We present the case of a 56-year-old man with the clinical diagnosis of ocular melanoma. As a part of staging, he underwent an F-18 FDG PET/CT scan for investigating distant metastasis. On PET scan, an increased focal area of F-18 FDG uptake was seen behind patient's right knee that can be confused with distant metastasis. On CT scan, there was a fluid density in the same location. The probable diagnosis was Baker's cyst. Later, USG and MRI confirmed this diagnosis. (MIRT 2012;21:75-76)

Key words: Fluorodeoxyglucose F18, positron emission tomography, popliteal cyst
\end{abstract}

\section{Özet}

Bu vakada oküler melanom tanılı 56 yaşında bir erkek hasta sunulmaktadır. Hastaya, evreleme aşamasında, uzak metastaz değerlendirmesi amacıyla F-18 FDG PET/BT çalışması yapıldı. PET görüntülerinde hastanın sağ dizinin arkasında, yanlışlıkla uzak metastaz olarak değerlendirilebilecek fokal artmış F-18 FDG tutulumu izlendi. BT görüntülerinde bu alanda sıvı dansitesi mevcuttu ve sonuçta bu bulgunun Baker kistine bağlı olabileceği düşünüldü. Daha sonra yapılan USG ve MR bu tanıyı doğruladı. (MIRT 2012:21:75-76)

Anahtar kelimeler: Fluorodeoksiglukoz F18, pozitron emisyon tomografi, popliteal kist

\section{Introduction}

$\mathrm{PET} / \mathrm{CT}$ is a challenging imaging modality in oncology and it can be used in diagnosing, staging, restaging and evaluating response to therapy. There are numerous reports in the literature about PET/CT interpretation pitfalls. In this case, we report a Baker's cyst in a patient with ocular melanoma, accumulating F-18 FDG on PET scan, that can be confusing by mimicking distant metastasis.

\section{Case Report}

A 56-year-old man was referred to an opthalmologist with a complaint of progressive vision loss in his left eye for 4 months. After clinical evaluation, the diagnosis was ocular melanoma. As a part of staging, he underwent an F-18 FDG
PET/CT scan for investigating distant metastasis. In the PET/CT study, sixty minutes after an intravenous injection of $11.1 \mathrm{mCi}$ F-18 fluorodeoxyglucose (FDG) with the patient fasting over 8 hours, an increased focal area of F-18 FDG uptake was seen behind patient's right knee on PET scan (SUVmax 3.2) (Figure 1). On CT scan, there was a fluid density in the same location. The probable diagnosis was Baker's cyst for this finding. Later, USG and MRI confirmed this diagnosis.

\section{Literature Review and Discussion}

Baker's cyst represents a fluid distention of a bursa between the gastrocnemius and semimembranosus tendons through a communication with the knee joint $(1,2)$. Baker's cyst can appear clinically as a posterior knee 
mass, mimicking a true soft tissue mass (2). The clinical presentations of Baker's cyst are; local pain, swelling, posterior knee tightness feeling on walking or activity and a palpable mass along the medial side of the popliteal fossa (2). In adults, Baker's cyst may be caused by an inflammatory joint disease or mechanical intra-articular derangements of the knee joint (3). The most frequent associated arthropathy of Baker's cyst is osteoarthritis (50.6 \%) (2). Observations suggest that the presence of Baker's cysts in knees with chronic osteoarthritic pain is associated with synovial inflammation and its grade (1). Baker's cyst can be seen up to $46 \%$ in different studies which evaluated patients with different diagnostic modalities in rheumatology clinics (2). Commonly used modalities are MRI and USG. The prevalence of Baker's cyst was between $0 \%$ and $2 \%$ in control groups in different studies $(1,5)$.

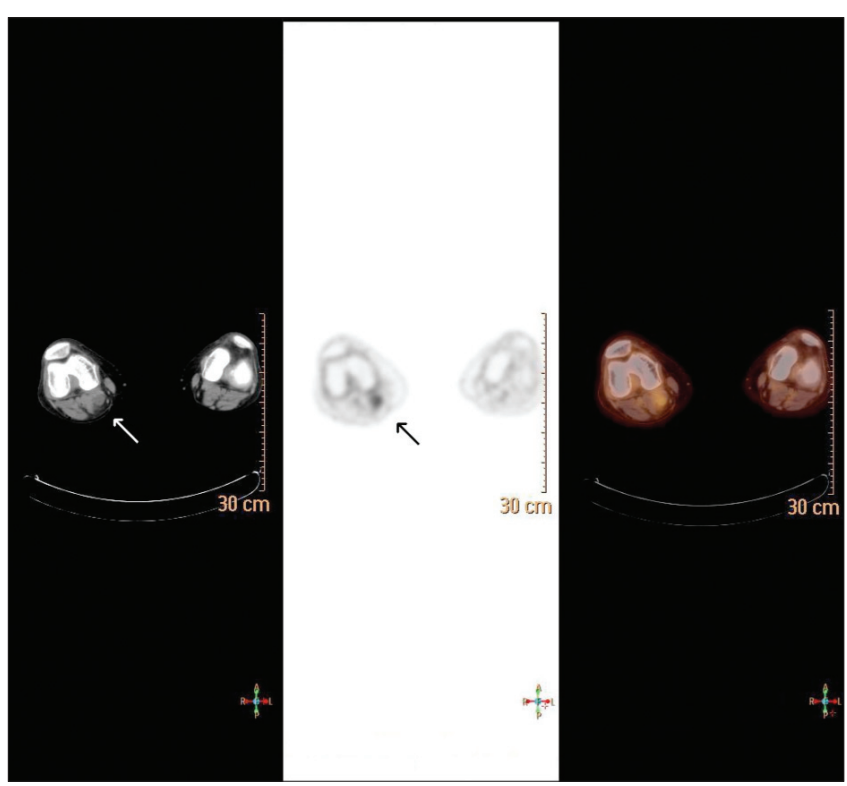

Figure 1. Axial slices of F-18 FDG PET/CT study showing an increased focal uptake behind patient's right knee on PET scan (SUVmax 3.2) (black arrow). A fluid density on CT scan in the same location compatible with Baker's Cyst (white arrow)
Treatment of the underlying disorder, steroid injection to ease the pain and surgery are the options for treatment (3).

There are numerous reports in the literature about PET/CT interpretation pitfalls. Lesions with a high concentration of inflammatory cells, such as neutrophils and activated macrophages, also show increased F-18 FDG uptake, which can be mistaken for malignancy or distant metastasis in patients with proven or suspected cancer (6).

Although the most common site of metastasis is the regional lymph nodes, and the distant metastases, elsewhere in the body are less common, we know that melanoma can occur in almost any organ of the body (7). Therefore, a lesion which accumulates F-18 FDG can be misinterpreted as distant metastasis in a melanoma patient. However; our knowledge, which is synovial inflammation and inflammatory joint disease are common pathological findings in Baker's cyst, makes interpretation easier.

\section{References}

1. Chatzopoulos D, Moralidis E, Markou P, Makris V, Arsos G. Baker's cyst in knees with chronic osteoarthritic pain: a clinical, ultrasonographic, radiographic and scintigraphic evaluation. Rheumatol Int 2008;29:141-146.

2. Liao S, Chiou C, Chang C. Pathology associated to the baker's cyst: a musculoskeletal ultrasound study. Clin Rheumatol 2010;29:1043-1047

3. Fritschy D, Fasel J, Imbert JC, Bianchi S, Verdonk R, Wirth CJ. The popliteal cyst. Knee Surg Sports Traumatol Arthrosc 2006;14:623628. Epub 2005 Dec 14.

4. Marti-Bonmati L, Molla E, Dosda R, Casillas C, Ferrer F. MR imaging of Baker cysts-Prevalence and relation to internal derangements of the knee. MAGMA 2000;10:205-210.

5. Rupp S, Seil R, Jochum P, Kohn D. Popliteal cysts in adults. Prevalence, associated intraarticular lesions, and results after arthroscopic treatment. Am J Sports Med 2002;30:112-115.

6. Abouzied MM, Crawford ES, Nabi HA. F-18 FDG imaging: pitfalls and artifacts. J Nucl Med Technol 2005;33:145-155.

7. Lanitis S, Papaioannou N, Sqourakis G, Seitz A, Zacharakis E, Karaliotas C. Prolonged survival after the surgical management of a solitary malignant melanoma lesion within the pancreas: A case report of curative resection. J Gastrointestin Liver Dis 2010;19:453-455. 